\title{
ANALISIS PENGARUH PEMASARAN MEDIA SOSIAL INSTAGRAM, PERSEPSI BIAYA PENDIDIKAN DAN BRAND RECOGNITION TERHADAP KEPUTUSAN PEMBELIAN PADA STIE WIYATAMANDALA
}

\author{
Sutrisno \\ Sekolah Tinggi Ilmu Ekonomi Wiyatamandala \\ an.trisno.jo@gmail.com
}

\begin{abstract}
The increasing complexity of competition has made business actors including STIE Wiyatamandala more able to survive and continue to grow. Therefore, it is necessary to analyze the variables that are relevant to student decisions in choosing STIE Wiyatamandala. This research was conducted with the aim of analyzing the effect of social media instagram, perception of education cost, and brand recognition on student purchasing decisions. From the results of the analysis, it was found that the variables of Instagram social media marketing, price perception, and brand recognition had a significant positive effect on purchasing decisions, and price perception was considered the variable that had the most positive influence on purchasing decisions. These population data were collected from Wiyatamandala students batch 2016 - 2019, with number of samples of 61 people respondents. The sample was chosen by using purposive sampling technique. Primary data were collected by using questionnaire method and analyzed by SPSS using multiple linear regression analysis Based on the research results, it was found that the variables of social media instagram (X1), perception of education cost (X2), and brand recognition (X3) had a significant positive effect on purchasing decisions (Y). The perception of education cost is considered to be the variable with the most positive influence on purchasing decisions
\end{abstract}

Keywords: Social Media Instagram, Perceptions of Education Costs, Brand Recognition and Purchase Decisions.

\section{PENDAHULUAN}

Di era globalisasi ini, kompleksitas dunia bisnis semakin meningkat dengan metamorfosis yang berkesinambungan. Perkembangan bisnis tersebut juga mengakibatkan adanya perubahan pola dan cara persaingan dalam mempertahankan bisnisnya. Oleh karena itu, setiap pelaku bisnis harus selalu meningkatkan kemampuannya untuk menarik keputusan pembeli agar mampu berhasil dalam menjalankan usahanya. Cara yang dilakukan untuk mencapai keberhasilan dalam 
menjalankan suatu bisnis salah satunya dengan melakukan kegiatan pemasaran. Pemasaran berhubungan dengan mengidentifikasi dan memenuhi kebutuhan masyarakat serta kebutuhan pelanggan secara menguntungkan (Kotler dan Keller, 2016 ). Pendidikan merupakan salah satu faktor penting bagi kemajuan dan perkembangan suatu bangsa. Baik pendidikan formal maupun informal berpengaruh besar bagi peningkatan pola berpikir generasi muda. Sejalan dengan pentingnya pendidikan, maka sektor pendidikan sendiri telah tumbuh menjadi satu industri yang besar yang bahkan sudah menjadi bidang bisnis tersendiri. Banyak grup usaha yang sudah sukses di bisnis lain berlomba-lomba turut memasuki dunia bisnis pendidikan baik pendidikan di tingkat dasar, menengah sampai pendidikan tinggi (universitas). Seiring masifnya pertumbuhan lembaga-lembaga pendidikan tinggi tersebut, tingkat persaingan antar perguruan tinggi juga menjadi semakin ketat. Selain peningkatan mutu yang harus diupayakan terus menerus, masing-masing lembaga pendidikan menciptakan program promosi untuk menarik minat para calon mahasiswa untuk mendaftar. STIE Wiyatamandala selaku School of Business yang berlokasi di Jl. Mangga Dua Raya no. 8 Blok 20-22 Jakarta mencanangkan visi menjadi "Sekolah Bisnis unggul dan diakui di tingkat nasional yang menyiapkan lulusan andal, berkemampuan wirausaha dan memiliki kepedulian sosial”. $\quad$ STIE Wiyatamandala juga terus berupaya meningkatkan kualitasnya untuk menjaring banyak calon mahasiswa dengan berbagai strategi pemasaran yang dilakukan saat ini, diantaranya pemasaran melalui media sosial (social media marketing), penetapan harga (biaya perkuliahan) yang kompetitif dan terjangkau, beasiswa hingga $100 \%$ serta fasilitas berkelas, pemilihan program studi dan ketersediaan kelas perkuliahan dengan waktu yang fleksibel, sebagai bagian dari brand recognition yang diciptakan. Penelitian ini bertujuan untuk menganalisis faktor- faktor yang mempengaruhi keputusan mahasiswa yang akhirnya memilih STIE Wiyatamandala sebagai tempat studinya. Oleh karena itu, diambil judul penelitian analisis pengaruh pemasaran media sosial instagram, persepsi biaya pendidikan dan brand recognition terhadap keputusan pembelian pada STIE wiyatamandala. Berdasarkan latar 
belakang yang diuraikan di atas ditetapkan rumusan masalah dalam penelitian ini, yaitu:

a. Sejauh mana pengaruh pemasaran melalui media sosial instagram terhadap keputusan pembelian mahasiswa yang memilih STIE Wiyatamandala.

b. Sejauh mana pengaruh persepsi biaya pendidikan terhadap keputusan pembelian mahasiswa yang memilih STIE Wiyatamandala.

c. Sejauh mana pengaruh brand recognition terhadap keputusan pembelian mahasiswa yang memilih STIE Wiyatamandala.

\section{TINJAUAN PUSTAKA}

Pemasaran melalui media sosial instagram.

Pemasaran merupakan proses dimana perusahaan menciptakan nilai bagi pelanggan dan membangun hubungan pelanggan yang kuat untuk menangkap nilai dari pelanggan (Kotler \& Amstrong, 2014). Proses pemasaran perlu untuk mengetahui kebutuhan dan keinginan konsumen. Salah satu aspek yang menjadi titik fokus pelaku bisnis dalam memasarkan produknya adalah melalui promosi. Promosi adalah suatu penyampaian informasi atau menawarkan suatu produk dan jasa kepada konsumen. Menurut Rangkuti (2009), promosi adalah kegiatan penjualan dan pemasaran dalam rangka menginformasikan dan mendorong

permintaan terhadap produk, jasa, dan ide dari perusahaan dengan cara memengaruhi konsumen agar mau membeli produk dan jasa yang dihasilkan oleh perusahaan. Promosi juga pada hakekatnya merupakan suatu bentuk komunikasi pemasaran dengan cara menyebar informasi, mempengaruhi, atau membujuk, dan mengingatkan pasar sasaran dan produknya agar bersedia menerima, membeli, dan loyal pada produk yang ditawarkan (Tjiptono, 2008) pemasaran di bidang jasa pendidikan telah menjadi tantangan tersendiri. Diperlukan kreativitas dan fleksibilitas dari pihak perguruan tinggi jika ingin memenangkan persaingan. Faktor persaingan yang semakin meningkat menyebabkan perguruan tinggi perlu 
untuk melakukan pembenahan, bukan hanya dari segi promosi namun juga dari faktor lain seperti penetapan harga (biaya pendidikan), fasilitas, program studi yang ditawarkan, waktu kuliah yang fleksibel (produk) dsb. Unsurunsur bauran pemasaran diolah sedemikian rupa untuk meningkatkan daya tarik bagi calon mahasiswa dan akhirnya dapat menjadi keunggulan kompetitif bagi masing-masing perguruan tinggi. Dalam penelitian ini, pemasaran difokuskan pada promosi melalui media sosial instagram. Media sosial diartikan sebagai aplikasi online, sarana, dan media yang ditujukan untuk memfasilitasi interaksi, kolaborasi, dan sharing materi (Richter dan Koch dalam Santoso, 2012). Media sosial memunculkan sosial media marketing untuk membujuk konsumen dengan media sosial pada suatu perusahaan atau pelaku bisnis dalam memperkenalkan dan memasarkan suatu produk atau jasa yang ditawarkan. Pemasaran melalui media sosial dilatarbelakangi oleh kemajuan teknologi dan internet. Media sosial saat ini telah menjadi bentuk media komunikasi dan promosi yang efektif. Para pelaku bisnis memanfaatkan kemajuan teknologi dengan memasarkan produknya melalui internet khususnya media sosial sebagai salah satu media untuk mempromosikannya. Ada berbagai platform media sosial yang dapat digunakan sebagai alat promosi baik bagi usaha perorangan maupun perusahaan, diantaranya adalah Facebook, Instagram, Twitter, Snap chat, dll. Berdasarkan informasi yang dilansir dalam websindo.com dalam artikel nya yang berjudul "Indonesia Digital 2019: Media Sosial” ditampilkan bahwa di Indonesia total pengguna aktif media sosial mencapai 150 juta orang $( \pm 56 \%$ dari jumlah penduduk) dengan 130 juta orang diantaranya adalah pengguna aktif media sosial dengan menggunakan smartphone $( \pm \quad 48 \%$ dari jumlah penduduk). Profile para pengguna media sosial terbanyak baik pria maupun wanita adalah di usia produktif yaitu 18-34 tahun. Sedangkan tiga besar platform media sosial yang paling aktif digunakan di Indonesia yakni nomor satu diduduki oleh Youtube $(88 \%)$, disusul yang kedua Facebook $(81 \%)$ dan yang ketiga Instagram $(80 \%)$. 
Instagram

Instagram diluncurkan pada tahun 2010 dan diakuisisi oleh Facebook ditahun 2012 setelah peluncuran. Instagram adalah sebuah aplikasi media sosial yang digunakan untuk menggugah dan melihat foto pribadi yang bisa terkoneksi dengan teman dan keluarga tanpa batasan jarak dan waktu. Dengan kata lain Instagram merupakan sebuah aplikasi berbagi foto yang memungkinkan pengguna mengambil foto, menerapkan filter digital, dan membagikannya ke berbagai layanan jejaring sosial, termasuk milik Instagram sendiri. Instagram merupakan jaringan sosial yang sangat penting untuk penyampaian sebuah brand dikarenakan instagram merupakan jaringan sosial yang besar dan banyak users instagram yang menggunakan instagram untuk review sebuah produk. Singh dalam Diamond (2015) menjelaskan bahwa instagram merupakan segmen untuk anak muda terutama berumur 18-29 tahun. Instagram digunakan oleh pelaku bisnis dalam memasarkan produknya menjadi lebih mudah karena sasaran pertamanya adalah orang yang paling dekat dengannya, bisa juga melalui teman yang awalnya dari mulut ke mulut sambil menunjukan akun instagram, komunikasi tersebut sangat efektif bagi para penjual, dengan adanya media Instagram semakin mudahnya penjual menunjukkan foto atau catalog barang jualannya (Putri 2013). STIE Wiyatamandala juga menggunakan instagram sebagai salah satu media promosinya, dengan tujuan untuk menyasar para pengguna instagram dari generasi milenial (mulai usia 17 tahun), untuk itu diharapkan pesan-pesan yang ingin disampaikan melalui instagramnya dapat diterima dengan baik dan tepat sasaran.

Harga (Biaya Pendidikan).

Harga adalah sejumlah nilai yang diberikan konsumen untuk memperoleh manfaat memiliki atau menggunakan produk atau jasa (Kotler \& Armstrong, 2017). Harga adalah segala sesuatu yang harus konsumen berikan untuk mendapatkan produk atau jasa (Masterson \& Pickton, 2014). Harga seringkali digunakan sebagai indikator nilai dimana indikator tersebut dihubungkan dengan manfaat yang dirasakan atas suatu barang dan jasa. Sebagai indikator harga dapat dilihat dari segi keterjangkauan harga oleh konsumen, kesesuaian harga dengan 
kualitas jasa, daya saing harga dan kesesuaian harga dengan manfaat. Harga merupakan unsur bauran pemasaran yang bersifat fleksibel (dapat diubah dengan cepat) dan sekaligus merupakan faktor penting yang mempengaruhi pilihan pembeli. Dalam perusahaan jasa, kunci penetapan harga yang efektif adalah mengaitkan harga yang dibayar pelanggan dengan nilai yang mereka dapatkan. Faktor-faktor yang paling mempengaruhi penentuan harga jasa yaitu: Persaingan, Elastisitas Permintaan, dan Struktur Biaya (Lupiyoadi, 2014). Biaya menurut Supriyono (2013) adalah pengorbanan ekonomis yang dibuat untuk memperoleh barang atau jasa. Sedangkan biaya pendidikan menurut Supriadi (2010), merupakan salah satu komponen instrumental (instrumental input) yang sangat penting dalam penyelenggaraan pendidikan. Dapat dikatakan bahwa proses pendidikan tidak akan dapat berjalan tanpa dukungan biaya. Dalam penelitian ini, persepsi biaya pendidikan adalah keseluruhan pengorbanan finansial yang dikeluarkan oleh konsumen (orangtua mahasiswa atau mahasiswa) untuk keperluan selama menempuh pendidikan dari awal sampai berakhirnya pendidikan.

Brand Recognition (Pengenalan Merek).

Pengenalan produk membantu para konsumen untuk membangun perilaku terhadap merek dan kepercayaan untuk penilaian produk tersebut. Brand recognition (pengenalan merek) dimaksudkan para pembeli cukup mengetahui tentang kriteria untuk mengkategorikan, tapi bukan untuk mengevaluasi atau membedakan dengan produk lain dalam kategori produk yang sama. (Howard, 1989). Brand recognition (pengenalan merek) didefinisikan sebagai sejauh mana pembeli tahu mengenai kriteria untuk mengkategorikan suatu merek (Wijaya dan Diah, 2014). Pengukuran merek membantu konsumen untuk membangun sikap terhadap merek dan kepercayaan dalam penilaiannya itu. Menurut Durianto (2003), brand recognition adalah tingkah minimal dari kesadaran merek pada saat seseorang pembeli memilih suatu merek pada saat pembelian. Pengertian brand recognition dapat disimpulkan yaitu tingkat kesadaran dan kemampuan seorang konsumen dalam menanggapi 
suatu merek yang dapat diukur dari pengenalan atribut merek secara fisik atau ciri-ciri produk. Menurut Howard, terdapat beberapa indikator pengenalan merek yakni harga produk, keunggulan, lokasi, spesialisasi dan petunjuk produk (Howard, 1989)

Keputusan Pembelian

Dalam membuat keputusan pembelian pada suatu produk, pada dasarnya berkaitan erat dengan perilaku konsumen. Perilaku konsumen merupakan elemen penting dalam kegiatan pemasaran suatu produk yang perlu diketahui oleh perusahaan, karena perusahaan pada dasarnya tidak tahu tentang apa yang ada di benak konsumen pada saat sebelum, sedang, dan setelah membeli produk. Swasta dan Handoko (2008) mengemukakan bahwa perilaku konsumen adalah kegiatan-kegiatan individu yang secara langsung terlibat dalam mendapatkan dan mempergunakan barang dan jasa, termasuk di dalamnya proses pengambilan keputusan pada persiapan

\section{METODOLOGI PENELITIAN}

Jenis penelitian yang digunakan adalah penelitian kuantitatif. Pendekatan kuantitatif memiliki fungsi untuk dan penentuan kegiatan-kegiatan tersebut. Dalam pembuatan keputusan, konsumen lebih banyak dipengaruhi oleh kredibilitas sumber informasi yang lebih bersifat personal (seperti word of mouth, recommendations, etc.) dengan jalan mendorong konsumen untuk merekomendasikan jasa tersebut kepada rekan-rekannya (Rosita, 2009). Keputusan konsumen, yang diasumsikan sebagai keputusan mahasiswa merupakan salah satu faktor penting bagi keberadaan perguruan tinggi. Keputusan yang dipilih mahasiswa dalam melanjutkan studi ke perguruan tinggi adalah kunci bagi kelangsungan siklus sebuah perguruan tinggi karena mahasiswa merupakan aset bagi sebuah perguruan tinggi. Keputusan yang diambil oleh mahasiswa pada prinsipnya merupakan keputusan konsumen dalam memilih perguruan tinggi sebagai tempat untuk menuntut ilmu, yang secara garis besar dijelaskan dalam perilaku konsumen.

menggambarkan serta lebih memahami makna hasil dari data yang muncul (Sugiyono, 2013). Variabel pemasaran 
melalui media sosial instagram, persepsi biaya pendidikan, dan brand recognition sebagai variabel independent serta keputusan pembelian sebagai variabel dependent. Variabel independent adalah variabel yang mempengaruhi atau yang menjadi sebab terjadinya variabel dependent, sedangkan variabel dependent adalah variabel yang nilainya dipengaruhi oleh variabel independent (Sugiarto, 2015). Populasi dalam penelitian adalah mahasiswa Wiyatamandala angkatan 2016-2019. Populasi adalah sekumpulan individu yang memiliki karakteristik khas yang menjadi perhatian dalam suatu penelitian dalam ruang lingkup yang ingin diteliti (Sugiarto, 2017). Metode pengambilan sample yang digunakan adalah dengan teknik Purposive Sampling. Purposive sampling merupakan teknik penentuan sampel secara sengaja dimana informasi diperoleh menggunakan pertimbangan tertentu yang disesuaikan dengan tujuan atau masalah penelitian. Pada penelitian ini diambil sampel sebanyak 61 responden mahasiswa STIE Wiyatamandala. Penelitian ini menggunakan data primer yang bersumber pada kuesioner yang dilakukan pada awal bulan Desember 2019 s/d 30 Januari 2020. Alat analisisnya menggunakan analisis regresi dengan bantuan software SPSS. Atas dasar kaitan logis antar variabel pemasaran media sosial instagram, persepsi biaya pendidikan dan brand recognition terhadap variabel keputusan pembelian, dikembangkan model penelitian berikut:

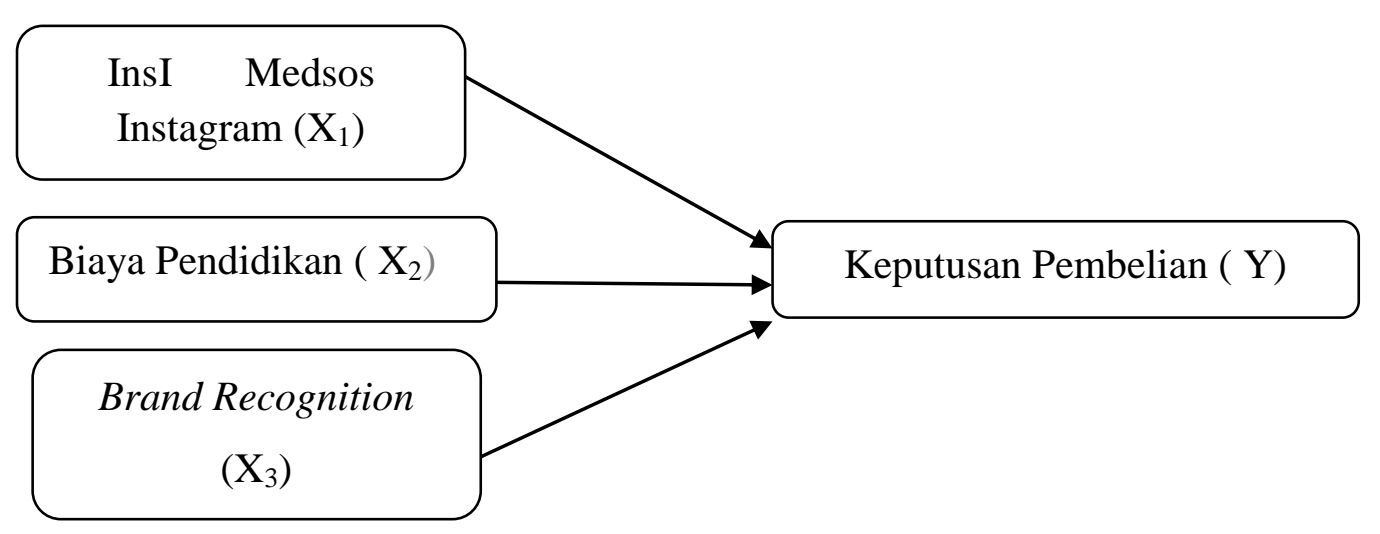

Gambar 1 Kerangka Pemikiran 
Hipotesis

Hipotesis dalam penelitian ini adalah :

1. Pemasaran melalui media sosial instagram berpengaruh positif terhadap keputusan pembelian.
2. Persepsi biaya pendidikan berpengaruh positif terhadap keputusan pembelian.

3. Brand recognition berpengaruh positif terhadap keputusan pembelian.

\section{HASIL DAN PEMBAHASAN}

Hasil Uji Instrumen Data Penelitian

Table 1 Karakteristik Customer

$\begin{array}{ccc}\text { Jenis Kelamin } & \text { Jumlah } & \text { Persen (\%) } \\ \text { Laki-laki } & 25 & 41 \\ \text { Perempuan } & 36 & 59 \\ \text { Total } & 61 & 100 \\ & & \text { Persen (\%) } \\ \text { Usia } & \text { Jumlah } & 100 \\ 18-31 & 61 & \text { Persen (\%) } \\ & & 46 \\ \text { Pekerjaan } & \text { Jumlah } & 54 \\ \text { Pelajar / mahasiswa } & 28 & 100 \\ \text { Karyawan } & 33 & \\ \text { Jumlah } & 61 & \end{array}$

Uji Reliabilitas.

Uji reliabilitas dilakukan untuk mengukur tingkat konsistensi antara hasil pengamatan dengan instrumen atau alat ukur yang digunakan pada waktu yang berbeda. Teknik yang digunakan untuk mengukur reliabilitas pengamatan adalah Cronbach Alpha. Teknik tersebut membandingkan nilai alpha dengan standarnya, berdasarkan ketentuan jika: a. Cronbach Alpha > 0,7 maka instrumen pengamatan dinyatakan reliabel.

b. Cronbach Alpha $<0,7$ maka instrumen pengamatan tidak reliabel.

Variabel $\mathrm{X}_{1}$ (Media Sosial Instagram).

Dari hasil uji reliabilitas terhadap 9 indikator untuk variabel $\mathrm{X}_{1}$ diperoleh capaian Cronbach's Alpha 0,913. Nilai Cronbach's Alpha 0,913 yang diperoleh 
sudah melebihi 0,7 dengan demikian indicator-indikator yang diuji telah memenuhi kaidah sebagai indikatorindikator yang reliable. Terhadap capaian tersebut tidak dimungkinkan lagi untuk meningkatkan besarnya Cronbach Alpha maka digunakan $\mathrm{X}_{14}$, $X_{15}, \quad X_{16}, \quad X_{17}, \quad X_{18}, \quad X_{19}$ sebagai indicator-indikator dari variabel $\mathrm{X}_{1}$. Adapun indikator-indikator $\mathrm{X}_{11}, \mathrm{X}_{12}$ dan $\mathrm{X}_{13}$ tidak digunakan sebagai indikatorindikator dari variabel $\mathrm{X}_{1}$. Berdasarkan uji reliabilitas di atas menunjukkan bahwa tampilan instagram Wiyatamandala menarik, informatif, dan bermanfaat bagi followers-nya karena memberikan informasi-informasi yang dibutuhkan oleh calon mahasiswa.

Variabel $\mathrm{X}_{2} \quad$ (Persepsi Biaya Pendidikan).

Dari hasil uji reliabilitas terhadap 7 indicator untuk variabel $X_{2}$ tersisa $X_{21}$ dan $\mathrm{X}_{22}$ sebagai indicator-indicator dengan Cronbach's Alpha mencapai 0,907. Nilai Cronbach's Alpha sebesar 0,907 yang diperoleh sudah melebihi 0,7 dengan demikian indikator-indikator yang diuji telah memenuhi kaidah sebagai indikator-indikator yang reliable. Adapun indikator-indikator $X_{23}, X_{24}, \quad X_{25}, X_{26}$ dan $X_{27}$ tidak digunakan sebagai indikator-indikator dari variabel $X_{2}$. Berdasarkan uji reliabilitas terhadap Persepsi biaya pendidikan menunjukkan bahwa biaya kuliah di STIE Wiyatamandala terjangkau, ditambah dengan pembayaran yang dapat dicicil dan beasiswa yang disediakan bagi mahasiswa yang berprestasi.

\section{Variabel $\mathrm{X}_{3}$ (Brand Recognition).}

Dari hasil uji reliabilitas terhadap 5 indicator untuk variabel $\mathrm{X}_{3}$ hanya digunakan $X_{33}$ dan $X_{34}$ sebagai indicator-indicator dengan Cronbach's Alpha mencapai $0,761 . \quad$ Nilai Cronbach's Alpha sebesar 0,761 yang diperoleh sudah melebihi 0,7 dengan demikian indicator-indikator yang diuji telah memenuhi kaidah sebagai indikator-indikator yang reliable. Adapun indikator-indikator $\mathrm{X}_{31}, \mathrm{X}_{32}$, $\mathrm{X}_{35}$ tidak digunakan sebagai indikatorindikator dari variabel $\mathrm{X}_{3}$. Berdasarkan uji reliabilitas terhadap brand recognition, diketahui bahwa mahasiswa berminat memilih STIE Wiyatamandala karena STIE Wiyatamandala menyediakan kelas pagi dan malam yang dirasa dapat menjawab kebutuhan karyawan, karena waktunya bisa disesuaikan dengan waktu mereka. 
Variabel Y (Keputusan Pembelian).

Dari hasil uji reliabilitas terhadap 11 indicator untuk variabel $\mathrm{Y}$ didapat Cronbach's Alpha sebesar 0,864 yang diperoleh dari 8 indikator final. Indikator-indikator $\mathrm{Y}_{1}, \mathrm{Y}_{2}$ dan $\mathrm{Y}_{11}$ tidak digunakan sebagai indicatorindikator dari variabel Y. Nilai Cronbach's Alpha sebesar 0,864 yang diperoleh sudah melebihi 0,7 dengan demikian indikator-indikator yang diuji telah memenuhi kaidah sebagai indikator-indikator yang reliable. Berdasarkan uji reliabilitas terhadap keputusan pembelian, diketahui bahwa mahasiswa yang mengambil keputusan untuk kuliah di STIE Wiyatamandala karena harganya terjangkau, pembayaran biaya kuliahnya bisa di cicil, tersedia beasiswa bagi mahasiswa yang berprestasi, ketersediaan pilihan kelas pagi dan malam (kelas karyawan) dimana waktunya bisa disesuaikan dengan waktu mereka serta program studi jurusan bisnis sesuai dengan peminatan mereka.

Uji Validitas.

Instrumen dikatakan valid apabila mampu mengukur apa yang diinginkan. Menurut Arikunto (2010) sebuah instrumen dikatakan valid apabila dapat mengungkapkan data dari variabel yang diteliti secara tepat. Valid tidaknya suatu item instrumen dapat diketahui dengan membandingkan indeks korelasi Product Moment Pearson dengan taraf signifikasi sebesar 5\% sebagai nilai kritisnya. Uji validitas dilakukan terhadap indikator-indikator variabel penelitian yang telah lolos dari uji reliabilitas. Untuk uji validitas terhadap indikator-indikator yang sudah reliable di dapati semua indikator tersebut memenuhi kaidah validitas sebagaimana terlihat pada tabel berikut. Sig (1-tailed) dari semua indikator tersebut dibawah nilai 0,05 . 
Tabel 2 Pearson Correlation dan signifikansinya untuk uji validitas

\begin{tabular}{|c|c|c|c|c|c|c|c|}
\hline $\begin{array}{c}\text { Indikator } \\
\mathrm{X}_{1}\end{array}$ & $\begin{array}{c}\text { Total } \\
\mathrm{X}_{1}\end{array}$ & $\begin{array}{c}\text { Indikator } \\
\mathbf{X}_{2}\end{array}$ & Total $X_{2}$ & $\begin{array}{c}\text { Indikator } \\
\mathbf{X}_{3}\end{array}$ & Total $\mathbf{X}_{3}$ & $\begin{array}{c}\text { Indikator } \\
\text { Y }\end{array}$ & Total Y \\
\hline $\mathrm{X}_{14}$ & $0,875^{*} * *$ & $\mathrm{X}_{21}$ & $0,716^{* * *}$ & $\mathrm{X}_{33}$ & $0,709 * * *$ & $\mathrm{Y}_{3}$ & $0,660 * * *$ \\
\hline $\mathrm{X}_{15}$ & $0,842 * * *$ & $X_{22}$ & $0,749 * * *$ & $\mathrm{X}_{34}$ & $0,604 * * *$ & $\mathrm{Y}_{4}$ & $0,734 * * *$ \\
\hline$X_{16}$ & $0,901 * *$ & & & & & $Y_{5}$ & $0,753 * * *$ \\
\hline $\mathrm{X}_{17}$ & $0,862 * * *$ & & & & & $Y_{6}$ & $0,611 * * *$ \\
\hline $\mathrm{X}_{18}$ & $0,754 * * *$ & & & & & $Y_{7}$ & $0,696^{* * *}$ \\
\hline \multirow[t]{3}{*}{$\mathrm{X}_{19}$} & $0,780 * * *$ & & & & & $\mathrm{Y}_{8}$ & $0,637 * * *$ \\
\hline & & & & & & $\mathrm{Y}_{9}$ & $0,762 * * *$ \\
\hline & & & & & & $Y_{10}$ & $0,646^{* * *}$ \\
\hline
\end{tabular}

Keterangan: $* * *$ signifikan pada alpha 0,01

\section{Analisis Regresi}

Analisis regresi merupakan salah satu metode statistika yang digunakan untuk menjelaskan hubungan fungsional antara variabel yang dinyatakan dalam suatu model atau persamaan. Model regresi sebagai alat untuk menerangkan, memahami, mengendalikan, dan memprediksikan hubungan antara variabel yang diteliti. (Sugiarto, 2017) Terhadap data yang telah melalui tahapan uji reliabilitas dan validitas instrument diperoleh statistika deskriptif sebagaimana tertera pada tabel berikut:

Tabel 3. Statistik Deskriptif

\begin{tabular}{cccc} 
& \multicolumn{2}{c}{ Descriptive Statistics } & \\
& Mean & Std. Deviation & \\
$\mathrm{Y}$ & 3.860656 & .6774256 & 61 \\
$\mathrm{X}_{1}$ & 3.355191 & .7021629 & 61 \\
$\mathrm{X}_{2}$ & 3.844262 & .8541125 & 61 \\
$\mathrm{X}_{3}$ & 4.098361 & .7349585 & 61 \\
\hline
\end{tabular}

Pearson Correlation dari ke empat variabel yang menjadi perhatian tampak pada tabel 4 berikut. Didapati semua variabel independent $\left(\mathrm{X}_{1}, \mathrm{X}_{2}\right.$ dan $\left.\mathrm{X}_{3}\right)$ berhubungan positif signifikan terhadap variabel dependen (Y). Dari hasil analisis korelasi yang tampak pada
Tabel 4 diketahui bahwa variabel Media Sosial Instagram $\left(\mathrm{X}_{1}\right)$, Persepsi Biaya Pendidikan $\left(\mathrm{X}_{2}\right)$ dan Brand Recognition $\left(\mathrm{X}_{3}\right)$ sebagai variabel independent, berhubungan positif signifikan terhadap Keputusan Pembelian (Y) sebagai variabel dependent. 
Tabel 4 Correlations antar Variabel

\begin{tabular}{rrrrrr} 
& & \multicolumn{1}{c}{$\mathbf{Y}$} & \multicolumn{1}{c}{$\mathrm{X}_{1}$} & \multicolumn{1}{c}{$\mathbf{X}_{2}$} & \multicolumn{1}{c}{$\mathrm{X}_{3}$} \\
Pearson & $\mathrm{Y}$ & 1.000 & .437 & .462 & .451 \\
Correlation & $\mathrm{X}_{1}$ & .437 & 1.000 & .219 & .297 \\
& $\mathrm{X}_{2}$ & .462 & .219 & 1.000 & .224 \\
& $\mathrm{X}_{3}$ & .451 & .297 & .224 & 1.000 \\
Sig. (1-tailed) & $\mathrm{Y}$ &. & .000 & .000 & .000 \\
& $\mathrm{X}_{1}$ & .000 &. & .045 & .010 \\
& $\mathrm{X}_{2}$ & .000 & .045 &. & .041 \\
& $\mathrm{X}_{3}$ & .000 & .010 & .041 &. \\
& $\mathrm{Y}$ & 61 & 61 & 61 & 61 \\
& $\mathrm{X}_{1}$ & 61 & 61 & 61 & 61 \\
& $\mathrm{X}_{2}$ & 61 & 61 & 61 & 61 \\
& $\mathrm{X}_{3}$ & 61 & 61 & 61 & 61 \\
& & & & & \\
\hline
\end{tabular}

Tabel 5 Tabel ANOVA

\begin{tabular}{rr|rrrr} 
& $\begin{array}{r}\text { Sum of } \\
\text { Squares }\end{array}$ & $d f$ & $\begin{array}{r}\text { Mean } \\
\text { Square }\end{array}$ & F & Sig. \\
\hline Regression & 11,246 & 3 & 3,749 & 13,118 & $0,000^{\mathrm{b}}$ \\
Residual & 16,288 & 57 & 0,286 & & \\
Total & 27,534 & 60 & & & \\
\hline
\end{tabular}

a. Dependent Variable: $\mathrm{Y}$

b. Predictors: (Constant), $\mathrm{X}_{3}, \mathrm{X}_{2}, \mathrm{X}_{1}$

Dari tabel anova didapati bahwa persamaan regresi pada penelitian ini memenuhi kaidah model yang fit dengan nilai $\mathrm{F}$ sebesar 13,118 dengan sig 0,000. Dari persamaan regresi yang terbentuk didapati $R$ Square $=0,408$ dengan Adjusted $R$ Square $=0,377$. Dengan demikian kemampuan penjelas model tergolong pada kondisi moderat. 


\section{Tabel 6 Hasil Coefficients}

\begin{tabular}{rrrrrr} 
& \multicolumn{2}{r}{$\begin{array}{r}\text { Unstandardized } \\
\text { Coefficients }\end{array}$} & $\begin{array}{r}\text { Standardized } \\
\text { Coefficients }\end{array}$ & & \\
Model & $B$ & Std. Error & Beta & $t$ & Sig. \\
(Constant) & 0,833 & 0,492 & & 1,693 & 0,096 \\
$\mathrm{X}_{1}$ & 0,267 & 0,104 & 0,277 & 2,557 & 0,013 \\
$\mathrm{X}_{2}$ & 0,267 & 0,084 & 0,336 & 3,173 & 0,002 \\
$\mathrm{X}_{3}$ & 0,270 & 0,100 & 0,293 & 2,707 & 0,009 \\
\hline
\end{tabular}

Dari Tabel 6 diketahui bahwa semua Variabel Independent (X) secara parsial berpengaruh positif signifikan terhadap variabel dependent (Y) dengan sig <
0.05. Hasil analisis data terhadap bentuk hubungan variabel $\mathrm{Y}$ dengan variabel $\mathrm{X}_{1}, \mathrm{X}_{2}$ dan $\mathrm{X}_{3}$ secara simultan ditampilkan pada persamaan berikut:

Persamaan Regresi $\mathrm{Y}=0,833+0,267 \mathrm{X}_{1}+0,267 \mathrm{X}_{2}+0,270 \mathrm{X}_{3}$

Variabel independent yang pengaruhnya paling signifikan terhadap variabel dependent adalah variabel $\mathrm{X}_{2}$ dengan standardized coefficients beta 0.336. Nilai standardized coefficients beta variabel $\mathrm{X}_{2}$ ini adalah yang tertinggi dibandingkan variabel $\mathrm{X}_{1}$ dan $\mathrm{X}_{3}$. Variabel persepsi biaya pendidikan sebagai salah satu variabel independent, menunjukkan pengaruh paling signifikan terhadap keputusan pembelian sebagai variabel dependent, dengan standardized coefficients beta 0.336. Nilai standardized coefficients beta variabel persepsi biaya pendidikan $\left(\mathrm{X}_{2}\right)$ ini tertinggi dibandingkan variabel media sosial instagram $\left(\mathrm{X}_{1}\right)$ dan brand recognition $\left(\mathrm{X}_{3}\right)$.
Pengaruh Media Sosial Instagram terhadap Keputusan Pembelian.

Pemasaran melalui media sosial dilatarbelakangi oleh kemajuan teknologi dan internet. Media sosial saat ini telah menjadi bentuk media komunikasi dan promosi yang efektif. Promosi adalah bagian dari komunikasi yang terdiri atas pesan-pesan perusahaan yang didesain untuk menstimulasi terjadinya kesadaran (awareness), ketertarikan (interest), dan berakhir dengan tindakan pembelian (purchase) yang dilakukan oleh pelanggan terhadap produk atau jasa (Kotler dan Keller, 2016). Para pelaku bisnis memanfaatkan kemajuan teknologi dengan memasarkan 
produknya melalui internet khususnya media sosial sebagai salah satu media untuk mempromosikannya. Hal ini juga dilakukan oleh STIE Wiyatamandala sehingga gencar memanfaatkan media sosial dalam memasarkan jasa pendidikannya, yaitu a/l melalui instagram. Iklan yang dilakukan dengan memposting foto-foto kegiatan, video yang kreatif serta promosi lainnya. Hasil uji reliabilitas terhadap 9 indikator untuk variabel media sosial instagram diperoleh capaian Cronbach's Alpha 0,913. Nilai Cronbach's Alpha 0,913 yang diperoleh sudah melebihi 0,7 dengan demikian indikator-indikator yang diuji telah memenuhi kaidah sebagai indikator-indikator yang reliable. Terhadap capaian tersebut maka digunakan $\mathrm{X}_{14}, \mathrm{X}_{15}, \mathrm{X}_{16}, \mathrm{X}_{17}, \mathrm{X}_{18}$, $\mathrm{X}_{19}$ sebagai indicator-indikator dari variabel media sosial instagram $\left(\mathrm{X}_{1}\right)$. Indikator $\mathrm{X}_{14}$ menyebutkan Tampilan Instagram Wiyatamandala menarik (eye-catching), $\quad \mathrm{X}_{15} \quad$ Instagram Wiyatamandala saya rasakan bermanfaat karena banyak berisi content informasi bagi followernya. $X_{16}$ dan $X_{17}$ menyebutkan content instagram Wiyatamandala (video, foto, dll ) sangat menarik dan sangat informatif. $\mathrm{X}_{18}$ menyebutkan Instagram Wiyatamandala secara konsisten aktif memposting content-content informasi. $\mathrm{X}_{19}$ Saya banyak mendapatkan informasi mengenai Wiyatamandala dari Instagramnya. Dari indikator-indikator tersebut dapat diketahui bahwa tampilan content-content di instagram Wiyatamandala secara langsung menjadi alat promosi untuk membangun kesadaran konsumen agar dikenal publik. Durianto menyatakan bahwa informasi iklan mendukung pengenalan merek agar lebih dikenal oleh publik yang berpengaruh pada sikap dan keyakinan konsumen (Durianto, 2003 ). Sikap memainkan peranan utama dalam membentuk perilaku. Sikap menyebabkan orang berperilaku konsisten terhadap objek serupa (Kotler dan Keller, 2016). Sikap terhadap merek adalah sejauh mana pembeli mengharapkan merek untuk menghasilkan kepuasan dari kebutuhan khususnya (Wijaya dan Diah, 2014). Menurut Anggita di dalam Wijaya dan Diah, setelah pengenalan merek sesuai dengan keinginan dan kebutuhan, maka konsumen akan membentuk sikap, dan selanjutnya menambah tingkat kepercayaan konsumen. (Wijaya dan Diah, 2014). Semakin tinggi tingkat keyakinan atas merek, akan semakin 
tinggi pula keputusan pembelian konsumen (Howard dalam Wijaya dan Diah, 2014). Berdasarkan hasil pengujian, disimpulkan bahwa hipotesis Pemasaran melalui media sosial instagram berpengaruh positif terhadap keputusan pembelian terbukti dengan hasil perhitungan SPSS, nilai sig. Pemasaran/promosi melalui media sosial instagram berada diangka 0.013 atau dibawah 0.05, dengan kata lain pemasaran/promosi melalui media sosial instagram memiliki pengaruh yang positif dan signifikan terhadap Keputusan Pembelian. Dengan demikian apa yang menjadi tujuan promosi STIE Wiyatamandala menggunakan instagram untuk menyasar pengguna instagram dari generasi milenial dapat diterima dengan baik dan tepat sasaran.

Pengaruh Persepsi Biaya Pendidikan terhadap Keputusan Pembelian.

Harga merupakan salah satu unsur bauran pemasaran yang menghasilkan pendapatan. Unsur lainnya menghasilkan biaya. Biaya adalah pengorbanan ekonomis yang dibuat untuk memperoleh barang atau jasa (Supriyono, 2013). Biaya memiliki peranan penting dalam mempengaruhi konsumen dalam mengambil keputusan. Karena harus disesuaikan dengan kemampuan konsumen dan pertimbangan manfaat yang akan diterimanya. Biaya adalah persepsi manfaat yang diterima konsumen dibandingkan dengan pengorbanan yang dibayarkan berupa sejumlah dana tersebut. Konsumen akan merasa rela mengeluarkan biaya sebesar apapun asalkan konsumen dapat menerima manfaat yang sesuai dengan yang diharapkannya. Biaya pendidikan merupakan faktor yang sangat penting bagi konsumen dalam melakukan pengambilan keputusan membeli suatu produk atau jasa (Hidayat dalam Rosita, 2009). Dalam kerangka pemasaran harga yang dalam hal ini adalah biaya pendidikan berinteraksi langsung dengan seluruh elemen lain dalam bauran pemasaran. Harga seringkali digunakan sebagai indikator nilai dimana indikator tersebut dihubungkan dengan manfaat yang dirasakan atas suatu barang dan jasa. Jadi harga yang dirasa sesuai dengan manfaat yang diperoleh konsumen, akan membentuk persepsi harga yang baik. Dalam hal ini biaya pendidikan yang sesuai dengan manfaat yang diperoleh mahasiswa, membentuk persepsi biaya pendidikan 
yang baik. Dari sudut pandang mahasiswa, biaya pendidikan yang baik adalah biaya pendidikan yang terjangkau pada kondisi kualitas layanan yang baik. Sebagai indikator harga, dapat dilihat dari segi keterjangkauan harga (biaya) pendidikan oleh mahasiswa, kesesuaian harga (biaya) dengan kualitas layanan, kesesuaian harga (biaya) dengan manfaat yang diperoleh, daya saing harga, dsb. (Tjiptono, 2008 ). Dari hasil uji reliabilitas terhadap 7 indicator untuk variabel Persepsi biaya pendidikan $\left(X_{2}\right)$, tersisa $X_{21}$ dan $X_{22}$ sebagai indicator-indicator dengan Cronbach's Alpha mencapai 0,907. Nilai Cronbach's Alpha sebesar 0,907 yang diperoleh sudah melebihi 0,7 dengan demikian indikator-indikator yang diuji telah memenuhi kaidah sebagai indicator-indicator yang reliable. Adapun $X_{21}$ adalah Biaya kuliah program studi S1 Wiyatamandala murah dan $\mathrm{X}_{22}$ Biaya kuliah program studi S1 Wiyatamandala terjangkau. Hasil ini menunjukkan bahwa secara umum responden menilai biaya kuliah di STIE Wiyatamandala terjangkau, ada cicilan ringan, dan disediakan beasiswa hingga 100\%. Berdasarkan hasil pengujian, disimpulkan bahwa hipotesis persepsi biaya pendidikan berpengaruh positif terhadap keputusan pembelian terbukti dengan hasil perhitungan SPSS, nilai sig. Persepsi biaya pendidikan berada diangka 0.002 atau dibawah 0.05, dengan kata lain Persepsi biaya pendidikan memiliki pengaruh yang positif dan signifikan terhadap Keputusan Pembelian.

Pengaruh Brand Recognition terhadap Keputusan Pembelian.

Brand Recognition (pengenalan merek ) merupakan landasan untuk terciptanya sikap konsumen (Anggita dalam Wijaya dan Diah, 2014). Dari pengenalan merek, selanjutnya dievaluasi apakah pengenalan tersebut sesuai dengan keinginan dan kebutuhan konsumen dimana kesesuaian tersebut akan membentuk sikap konsumen. Menurut Wijaya dan Diah, sikap terhadap merek adalah sejauh mana pembeli mengharapkan merek untuk menghasilkan kepuasan dari kebutuhan khususnya (Wijaya dan Diah, 2014). Berdasarkan hasil pengujian, disimpulkan bahwa hipotesis brand recognition berpengaruh positif terhadap keputusan pembelian terbukti dengan hasil perhitungan SPSS, nilai sig. brand recognition berada diangka 
0.009 atau dibawah 0.05 , dengan kata lain brand recognition memiliki pengaruh yang positif dan signifikan terhadap keputusan pembelian. Hasil analisis tersebut menunjukkan pengenalan merek berpengaruh positif dan signifikan terhadap sikap atas merek, yang selanjutnya akan menambah tingkat kepercayaan konsumen dalam memutuskan pembelian. (Sutisna, 2012). Dari hasil uji reliabilitas terhadap 5 indicator untuk variabel brand recognition $\left(\mathrm{X}_{3}\right)$ hanya digunakan $\mathrm{X}_{33}$ dan $\mathrm{X}_{34}$ sebagai indikator-indicator dengan Cronbach's Alpha mencapai $0,761 . \quad$ Nilai Cronbach's Alpha sebesar 0,761 yang diperoleh sudah melebihi 0,7 dengan

\section{KESIMPULAN DAN SARAN}

Kesimpulan

Berdasarkan hasil uji analisis regresi berganda dapat ditarik kesimpulan bahwa semua variabel independent, yakni variabel pemasaran media sosial instagram $\left(\mathrm{X}_{1}\right)$, variabel persepsi biaya pendidikan $\left(\mathrm{X}_{2}\right)$, dan variabel brand recognition $\left(\mathrm{X}_{3}\right)$ berpengaruh positif signifikan terhadap variabel keputusan pembelian (Y) sebagai variabel dependent. Variabel independent (X) yang pengaruhnya paling signifikan terhadap variabel dependent (Y) adalah variabel $\mathrm{X}_{2}$ demikian indikator-indikator yang diuji telah memenuhi kaidah sebagai indikator-indikator yang reliable. Indikator $\mathrm{X}_{33}$ dan $\mathrm{X}_{34}$ adalah jasa pendidikan STIE Wiyaramandala adalah brand dengan biaya terjangkau dan program pendidikan STIE Wiyatamandala menyediakan kelas pagi dan malam, kelas karyawan, yang waktunya bisa disesuaikan dengan waktu mahasiswa. Dengan demikian beberapa indikator pengenalan merek yang disampaikan oleh Howard terpenuhi, dan brand recognition secara positif signifikan mempengaruhi keyakinan konsumen terhadap keputusan pembelian.

(persepsi biaya pendidikan). Dengan demikian persepsi biaya pendidikan merupakan daya tarik terpenting bagi mahasiswa yang memilih berkuliah di STIE Wiyatamandala.

Saran

Saran untuk pihak manajemen STIE Wiyatamandala :

1. Hasil penelitian ini diharapkan dapat menjadi referensi atau masukan bagi pengembangan ilmu manajemen dan menambah kajian ilmu manajemen tentang 
pemasaran melalui sosial media

marketing khususnya melalui media sosial Instagram.

2. Memperkuat branding kampus tidak hanya dengan biaya yang terjangkau, tetapi juga memperkenalkan fasilitas dan kenyamanan kampus, memperkenalkan dosen-dosen pengajar yang berpengalaman, dsb.

Saran peneliti untuk penelitian selanjutnya sebagai berikut :

1. Penelitian selanjutnya perlu menggunakan jumlah sample yang lebih banyak, hal ini

\section{DAFTAR PUSTAKA}

Arikunto, S. (2010). Prosedur

Penelitian Suatu Pendekatan Praktik. Jakarta: Rineka Cipta.

Diamond, Stephanie. (2015). The Visual Marketing Revolution. Jakarta: Serambi Ilmu Semesta

Durianto, Darmadi. (2003). Inovasi Pasar dengan Iklan yang Efektif. Jakarta: PT. Gramedia Pustaka Utama.

Howard, J.A.(1989). Consumer

Behaviour In Marketing Strategy. Englewood cliffs. NJ: Prentice Hall bertujuan untuk memperoleh konsistensi dan keakuratan dari hasil penelitian yang lebih besar.

2. Penelitian selanjutnya dilakukan pada lingkup media sosial yang lebih beragam, seperti dilakukan pada Facebook, Twitter, dsb. Hal ini bertujuan agar memaksimalkan penggunaan media sosial yang dimiliki STIE Wiyatamandala dalam menjalankan strategi pemasaran.

Kotler, Philip, Armstrong Gary (2014), Principles of Marketing, $15^{\text {th }}$ Edition, Global Edition. Pearson Education Limited, England.

Kotler, Philip, Armstrong Gary (2017), Marketing An Introduction, $13^{\text {th }}$ edition. Pearson Education Limited, England

Kotler, Philip, Kevin Lane Keller (2015). Marketing Management, 15e Global Edition. Pearson Education Limited, England.

Lupiyoadi, Rambat (2014). Manajemen Pemasaran Jasa Berbasis Kompetensi; Edisi ke-3. Jakarta: Salemba Empat. 
Masterson, Rosalind dan David Pickton (2014), Marketing An Introduction, $3^{\text {rd }}$ edition. California: SAGE Publication Ltd.

Putri EA. (2013). Aplikasi Instagram sebagai Media Komunikasi Pemasaran Online Shop (skripsi). Dapat diunduh di :http://eprints.upnjatim.ac.id/502 0/1/file1.pdf

Rangkuti F. (2009). Strategi Promosi yang Kreatif dan Analisis Kasus Integrated Marketing Communication. Jakarta (ID) : Gramedia Pustaka Utama.

Rosita, Jenny. (2009). Faktor-Faktor yang Mempengaruhi Mahasiswa dalam Mengambil Keputusan Memilih Universitas X di Surabaya, Jurnal Eksekutif, Vol. VI, No.2.

Santoso RK. (2012). Pengaruh Media Sosial Terhadap Customer Retetion. (Tesis). Depok (ID): Universitas Indonesia. Dapat diunduh di : http://lib.ui.ac.id/opac/ui/detail

Sugiarto, Prof. Dr, Ir. (2015). Metode Statistika Bisnis. Penerbit : PT. Matana Publising Utama, Paramount Skyline Complex, Tangerang - Indonesia.

Sugiarto, Prof. Dr, Ir. (2017), Metodologi Penelitian Bisnis. Yogyakarta: Penerbit Andi Offset.
Sugiyono (2013). Metode Penelitian Pendidikan (Pendekatan Kuantitatif, Kualitatif, dan $R \& D)$. Bandung : Alfabeta.

Supriadi Dedi, Prof. Dr, (2010). Satuan Biaya Pendidikan Dasar dan Menengah, Bandung : PT Remaja Rosdakarya.

Supriyono.R.A. Dr, (2013). Akuntansi Biaya, Pengumpulan Biaya dan Penentuan Harga Pokok. Yogyakarta : Penerbit Fakultas Ekonomi dan Bisnis UGM.

Sutisna. (2012). Perilaku Konsumen dan Komunikasi Pemasaran, Edisi Kedua, Bandung : Penerbit Remaja, Rosdakarya.

Swasta, Basu dan Hani Handoko.(2008). Manajemen Pemasaran : Analisis Perilaku Konsumen. Edisi Pertama Cetakan Keempat, Yogyakarta: BPFE UGM.

Tjiptono, Fandi. (2008), Strategi

Pemasaran. Edisi Ketiga. Yogyakarta: Penerbit Andi Offset.

Websindo.com dalam artikel berjudul Indonesia Digital 2019 : Media Sosial Wijaya, Noviany dan Diah Dharmayanti. (2014). Analisa Efektivitas Iklan Kosmetik Wardah dengan Menggunakan Consumer Desicion Model (CDM). Jurnal Manajemen Pemasaran Petra. Vol.2 No. 1. 